\title{
ACADEMIC HONESTY: PERCEPTIONS OF MILLENNIAL UNIVERSITY STUDENTS AND THE ROLE OF MODERATING VARIABLES
}

\begin{abstract}
Author:
Dr André van Zyl ${ }^{1}$

Adele Thomas ${ }^{2}$

\section{Affiliation:}

${ }^{1}$ Academic Development Centre (ADC), University of Johannesburg

${ }^{2}$ Department of Industrial Psychology and People Management, University of Johannesburg
\end{abstract}

\section{Correspondence to:} Dr André van Zyl

Email:

andrevz@uj.ac.za

\section{Postal address:}

727 27th Avenue, Villieria 0186, Pretoria, South

Africa

Correspondence to: Adele Thomas

Email:

adelet@uj.ac.za

\section{Dates:}

Accepted: 01 Jun. 2015 Published: 01 Sep. 2015

How to cite this article: Van Zyl, A. \& Thomas, A., 2015, 'Academic honesty: perceptions of millennial university students and the role of moderating variables', KOERS Bulletin for Christian Scholarship 80(1), Art. \#2210, 15pages. http:// dx.doi.org/10.19108/ koers.80.1.2210

\section{Copyright:}

(c) 2015. The Author(s). Published under the Creative Commons Atribution License.
Student academic dishonesty is increasing locally and internationally and universities are devising strategies to address this problem. The first year of academic study lays the foundation for future years of study and, as such, is critical in the establishment of adherence to academic values. As part of a larger project, the perceptions about academic honesty of first-year students belonging to the millennial generation at a large South African public university were obtained with a view to identifying trends in perceptions between the 2011 and 2012 student cohorts as well as the relationship between student sub-groups and perceptions held about academic honesty. The present study also sought to validate the findings of the 2011 study.

The population comprised all 22442 students entering the University for the first time during the 2011 and 2012 academic years. Combined Strategy Sampling, followed by cluster sampling was used to obtain a sample of 5730 students (3 611 in 2011 and 2119 in 2012), broadly representative of the institutional population. In this regard, the 2011 sample of Thomas and van Zyl (2012) (3 611 students) was combined with the sample of the present study (2 119). A questionnaire, developed from the literature, comprising 12 ethical statements was used as the survey instrument. The data for the 2012 student sample was compared to that obtained from the Thomas and van Zyl (2011) sample and, by means of Chi-square tests and Standardised Residuals, the statistical association between perceptions held by members of student sub-groups and perceptions about academic honesty was investigated.

The sample of both years of first-year students indicated a trend in perceptions and one that pointed to an understanding of the meaning of academic dishonesty yet a regard for it as a relative concept and one that is superseded by, for example, the belief that right and wrong is a matter of personal opinion, that ideas do not belong to anyone and that information is accessible and free. This implies that these students enter academia with perceptions about academic honesty that may differ to those founded on the value authenticity in academia. Differences in opinion were found amongst students of different language groups and the qualification for which they were registered.

It is recommended that the values of academia should be reinforced with this student group and that broad pedagogic approaches, whilst reinforcing these values, should be tailored and differentiated according to the specific nature of each faculty and with particular sensitivity to the writing needs of students who belong to different language groups.

Keywords: First year students; Academic honesty; millennials; plagiarism; ethics

Die insidensie van studente akademiese oneerlikheid is ' $n$ toenemende probleem beide op nasionale en internasionale vlak en universiteite is besig om strategieë in plek te sit om hierdie problem aan te spreek. Die eerste studiejaar is ' $n$ kritieke moment vir die vestiging van gepaste akademiese waardes omdat dit die fondament lê vir die daaropvolgende studiejare. Die huidige studie vorm deel van 'n groter projek wat die persepsies van sogenaamde milleniale generasie eerstejaarstudente oor akademiese eerlikheid by ' $n$ groot publieke universiteit in Suid Afrika ondersoek het. Die doel van die ondersoek was om tendense in die persepsies van studente wat tussen 2011 en 2012 die universiteit betree het asook die onderlinge verwantskappe tussen verskeie sub-groepe in verband met akademiese eerlikheid te ondersoek. Die huidige studie het ook gepoog om die bevindinge van die 2011 studie te valideer.

Die populasie waaruit die steekproef geneem is het bestaan uit al 22442 studente wat die Universiteit tydens die 2011 en 2012 akademiese jare vir die eerste keer betree het. Gekombineerde strategie steekproefneming, gevolg deur trossteekproefneming is gebruik om 'n steekproef van 
5730 studente (3 611 in 2011 en 2119 in 2012) te selekteer. Die steekproef was demografies gesproke verteenwoordigend van die institusionele student profiel. Vir die doel van hierdie studie is die 2011 steekproef van Thomas en van Zyl (2012) (3 611 studente) en die 2012 steekproef (2 119 studente) gekombineer. 'n Vraelys wat vanuit die litteratuur ontwikkel is en wat uit 12 eties gelaaide stellings bestaan het, is as navorsingsinstrument gebruik. Die data van die 2012 steekproef is vergelyk met die data van Thomas en van Zyl (2011) en die chi-kwadraat toets met gestandardiseerde residue is gebruik om die statistiese verband tussen verskillende sub-groepe en hul persepsies oor akademiese eerlikheid te ondersoek.

Tendense wat daarop dui dat studente die betekenis van akademiese oneerlikheid verstaan, maar dit as ' $\mathrm{n}$ relatiewe konsep beskou, was waarneembaar in beide steekproewe wat hier ondersoek is. Die studente het aangedui dat hul oortuiging dat "reg en verkeerd slegs 'n kwessie van persoonlike oortuiging is" en dat "idees nie aan iemand kan behoort nie maar dat hulle vryelik beskikbaar en bruikbaar moet wees" belangriker is as konsepte wat tradisioneel verband hou met akademiese oneerlikheid. Dit impliseer dat hierdie studente dikwels die akademie betree met persepsies oor akademiese oneerlikheid wat verskil van die tradisionele akademiese verstaan wat op die belangrikheid van egtheid in die akdedemie gegrond is. Die huidige studie het verskille in sienings gevind tussen verskillende taalgroepe asook tussen die verskillende studierigtings.

Hierdie studie beveel aan dat die waardes wat eie is aan die akademie duidelik gekommunikeer sal word in die groter studentegroep. Dit moet gedoen word deur algemene pedagogiese benaderings asook op pasgemaakte maniere wat die behoeftes en aard van verskillende fakulteite asook die verskillende skryfbehoeftes van verskillende taalgroepe in ag neem.

Sleutelwoorde: Eerstejaarstudente; akademiese eerlikheid; Millennials; plagiaat; etiek

\section{INTRODUCTION}

The first year of academic study is crucial to students' entry into higher education. Vast amounts of learning take place, different in nature and in level to that which students previously experienced. This first year of study also provides the foundation on which further academic success is built (Reason, Terenzini \& Domingo 2006). In addition, a link between student academic dishonesty and later dishonesty in the workplace has also been suggested (Jones 2011).

The present study is part of a larger study that explores the understanding of and perceptions about academic honesty amongst first-year or Millennial students at a large South African public university. While no exact generational definition exists, Millennial students are considered to be those of the generation born between 1982 and 2002
(Evering \& Moorman 2012) and who enter universities roughly between 2001 and 2021 (Gross 2011).

In 2012, Thomas and van Zyl reported the findings that emanated from the first cohort of students in this study. These Millennial students appeared ambivalent with regard to practices that constitute academic honesty, and tended to disregard the ownership of knowledge. They did, however, evidence an understanding of the meaning of terms that related to academic dishonesty, for example, cheating and plagiarism, but appeared to consider adherence to such behaviours as being relative in nature. As an example, copying during a test was regarded as a serious transgression but using the answers of a classmate in homework required to be performed individually was considered a lesser serious offence.

This article reports the findings of the second cohort of students, one year later.

The objectives of the present study were: (a) to canvas the perceptions of academic honesty of first-year students entering a large public university in 2012 and to compare these findings with those of the previous 2011 study (Thomas \& van Zyl 2012), with a view to validating the findings of the earlier study and, thereby identifying whether or not a trend in such perceptions exist; (b) to ascertain if significant differences exist among student sub-groups according to certain academic and demographic variables. The unique contribution of the present study is its extension of the Thomas and van Zyl (2012) study to include an investigation of the relationships between student perceptions of academic honesty according to the variables of gender, language, faculty of enrolment and qualification type.

Faculty and university administrators should understand the perceptions about academic honesty that first-year students hold. Such information could inform possible interventions to promote practices of academic honesty among students in this formative year.

Research into student academic dishonesty, or behaviour that runs counter to generally accepted norms of conduct (Shanahan et al. 2013), and perceptions regarding academic honesty/dishonesty is sparse in non-US countries (Teixeira \& Rocha 2010) and in non-western countries (Imran \& Nordin 2013). Accordingly, the present study also seeks to contribute to an understanding of the perceptions of student academic honesty in a country where, up to this point, little academic research has been published on this matter.

\section{LITERATURE REVIEW}

\section{Millennial students}

Millennials are characterised by self-confidence and selfreliance; they are technologically competent and are open to change; they are service-oriented, connected to family and social networks and expect immediate access to information (Young \& Hinesly 2012). They are especially adept at using the 
World Wide Web as a primary source to access information (Holliday \& Li 2004).

Millennial students pose a challenge to the traditional ways in which honesty and dishonesty have been framed in academia. This Internet generation of social communities interprets the concept of 'acceptable' according to their understanding of a free availability of knowledge, communal ownership of material and the bonds of social network relationships (Gross 2011). In this regard, the traditional academic values of academic honesty and the protection of the scientific record (Lewis et al. 2011) could be under threat by the 'borrowing' of the proprietary material by those who hold the view that information cannot be owned.

Millennial students regard technology as a primary source of communication which may shape their views on the value of intellectual property as the content of the Internet is free (Evering \& Moorman 2012). They are the 'Net Generation' where belonging to social communities encourages plagiarism "through the development of a shared understanding of what is acceptable" (Ma et al. 2008:198). Gross (2011) proposes that millennials regard information as communal property and view the concept of merit as being subjective. In this vein, Hutton (2006) believes that the Internet promotes strong social networks between students and weaker relationships between students and faculty where the rules of academic ownership are set and reinforced. Gross (2011) notes the shift from the traditional standard of viewing cheating as wrong and dishonest, to a post-modern value orientation amongst these students that locates this behaviour within the context of the situation and relationships.

\section{Student academic dishonesty and strategies to address the problem}

There is no common definition for the set of behaviours that constitute student academic dishonesty (Comas-Forgas et al. 2010). Cheating behaviour is an integral component of student academic dishonesty and generally includes cheating during tests or examinations, collaborating on assignments set as individual tasks, plagiarising or taking the work or ideas of others without proper attribution, copying work, fabricating work and purchasing assignments. Regardless of the precise definition of student academic dishonesty, the evidence suggests that such behaviour is on the increase (Anitsal et al. 2009; Jones 2011), resulting in universities experiencing "an integrity recession" (Voelker et al. 2012:36). Perhaps the most comprehensive studies of student academic dishonesty over the years have been conducted by McCabe (2005 and McCabe et al. (2012). McCabe et al. (2012) note how the incidence of cheating has remained high over the past years in spite of academic effort to address this phenomenon. Similarly, Teixeira \& Rocha (2010) report consistently high incidences of student cheating in an international study undertaken at 42 universities located in 21 countries. The ease of access to electronic sources has precipitated an increase, specifically, in one aspect of academic dishonesty, viz. plagiarism (Aasheim et al. 2012; Ma et al. 2008). The concept of 'student academic honesty' incorporates the opposite practices of those described above.

Measures to address academic dishonesty by students tend to be haphazard (Brimble \& Stevenson-Clarke 2006) with sanctions and discipline being the main actions adopted (Aasheim et al. 2012). Some institutions have attempted to offer instruction in responsible academic writing (Elander et al. 2010; Löfström \& Kupila 2013) along with clear examples of behaviours that are regarded as constituting cheating (Boehm et al. 2009) or have adopted assessment techniques that make cheating difficult (such as unusual or unique assignments and requirements to submit portfolios of evidence) (Hansen et al. 2011). Other institutions have attempted to promote moral reasoning in students (Schmidt et al. 2009) or have introduced courses on ethics (Beauvais et al. 2007). Honour codes and academic integrity programmes (Evering \& Moorman 2012; McCabe 2005), with the related development of strategies to promote student commitment to the values of the institution (Dix et al. 2014), have also been used

\section{Reasons for student academic dishonesty}

Divergent views exist about the reasons for student academic dishonesty (Leask 2006) and, it is suggested, such reasons can be classified into two broad groupings - situational and demographic.

When considering situational factors, it has been suggested that student values impact academic dishonesty (Imran \& Nordin 2013) and that such values are culturally-based (Peppas 2002). Anitsal et al. (2009) note the link between student cheating and the beliefs they hold as well as the norms to which they adhere. Teixeira \& Rocha (2010) found culture to influence the tendency of students to cheat and also found that students who attended universities in countries perceived to be corrupt evidenced higher incidences of academic dishonesty, leading them to conclude that "curbing cheating in the classroom may not be just a matter of targeted (higher) education policies but rather a change in attitude that is transversal to society as a whole" (Teixeira \& Rocha 2010:696). Leask (2006) reinforces the view that plagiarism, specifically, is a culturally constructed concept necessitating that academics recognise and engage with cultural diversity.

Ellery (2008), in a South African study, indicates that the schooling system poorly equips students with skills for academic writing. Similarly, Devlin \& Gray (2007) note how poor academic skills lead to student plagiarism, together with a poor understanding of plagiarism, poor quality of teaching and assessment, and student laziness.

Student cheating has been strongly correlated with the observation of others cheating (Fulks et al. 2010; O'Rouke et al. 2010; Rettinger \& Kramer 2009). In this regard, theorists have suggested that the broader institutional culture must be targeted to promote the spirit of integrity (Imran \& Nordin 2013; Piascik \& Brazeau 2010) and that the dishonesty of academic faculty themselves must be addressed (Parameswaran 2007). 
Among others, demographic factors linked to student dishonesty include gender, intelligence, self-confidence, extrinsic-intrinsic orientation, behaviour patterns and age.

Male business students have been found to be more likely to cheat than female students (Kisamore et al. 2007) which Teixeira \& Roche (2010) attribute to sex-role socialisation. Specifically, male millennial students evidence a higher incidence of academic dishonesty than female students depending on the form of academic dishonesty being considered (Hensley et al. 2013). Men are more likely to plagiarise and make false excuses but no gender differences have been found when considering undifferentiated practices of academic dishonesty (Williams et al. 2010).

Cheating has been linked to students who evidence low grades (Hensley et al. 2013), to those who lack self-confidence and have low self-esteem (Pittam et al. 2009), to those who lack knowledge of how to avoid cheating (Granitz \& Loewy 2007; Voelker et al. 2012), and to those who are extrinsically motivated (Rettinger \& Kramer 2009). Behaviour laziness or lack of conscientiousness (De Bruin \& Rudnick 2007) and an inherent lack of integrity (Evering \& Moorman 2012), have all been linked to student cheating. Older students have been found to be less likely to cheat than younger students (Kisamore et al. 2007).

Within the youthful age group, attributes of millennials, linked to the potential to behave dishonestly, have been noted to be: opportunism and expedience (Gross 2011), rule breaking where integrity is centred in the development of social relationships (Gross 2011), ambition and impatience, with feelings of entitlement based on social relationships not performance ( $\mathrm{Ng}$ et al. 2010), and confidence and teamorientation (Wilson 2004). Millennials also appear to be more concerned about outcome than process (Piascik \& Brazeau 2010). From the above, it is suggested the millennial students present a different academic profile to students of previous generations. Therefore the current intervention strategies to promote academic honesty amongst students may be ineffective for students from this new generation.

\section{METHOD}

\section{Population and sample}

The institution at which this study was conducted is a comprehensive university offering both degree and diploma programmes. Extended degrees and diplomas (qualifications that extend the original offerings by one year to augment modules and to supplement the academic foundation) are also offered.

The population comprised all first-year students entering the University for the first time during the 2011 and 2012 academic years. For the 2011 academic year, the researchers had access to the questionnaire and data used by Thomas and van Zyl (2012) for means of comparison. The combined population for the two years was 22442 (12 309 in 2011 and 10133 in 2012). Combined Strategy Sampling (Gravetter \& Forzano 2009) was used, involving stratified sampling of the population according to faculty, and then cluster sampling through subdivision within faculties according to qualification type. This technique ensured representation of the sample according to these strata. Convenience sampling was then used to gather data within each cluster.

This process resulted in the compilation of a database of 5 730 completed student questionnaires which complied with data quality requirements (3 611 in 2011 and 2119 in 2012). The biographic distribution of the sample, broadly representative of the institutional population, is provided in Tables 1 to 4 in which the results for the completed fields are shown, hence reflecting different total sample numbers.

\section{Table 1: Gender}

\begin{tabular}{|c|c|c|c|c|}
\hline \multirow[t]{2}{*}{ Gender } & \multicolumn{2}{|c|}{2011} & \multicolumn{2}{|c|}{2012} \\
\hline & $\mathrm{N}$ & $\%$ & $\mathrm{~N}$ & $\%$ \\
\hline Male & 1586 & 44.0 & 952 & 45.0 \\
\hline Female & 2015 & 56.0 & 1164 & 55.0 \\
\hline Total & 3601 & 100.0 & 2116 & 100.0 \\
\hline
\end{tabular}

Table 2: Age

\begin{tabular}{|l|r|r|r|}
\hline & \multicolumn{2}{|c|}{2011} & \multicolumn{2}{|c|}{2012} \\
& Nge & N & N \\
\hline 18 or younger & 926 & 32.5 & 760 \\
\hline
\end{tabular}




\begin{tabular}{|c|c|c|c|c|}
\hline $19-21$ & 1981 & 56.2 & 1112 & 53.9 \\
\hline $22-30$ & 400 & 11.3 & 187 & 9.1 \\
\hline Total & 3307 & 100.0 & 2059 & 100.0 \\
\hline
\end{tabular}

\section{Table 3: Qualification type}

\begin{tabular}{|c|c|c|c|c|}
\hline \multirow[t]{2}{*}{ Qualification } & \multicolumn{2}{|c|}{2011} & \multicolumn{2}{|c|}{2012} \\
\hline & $\mathrm{N}$ & $\%$ & $\mathrm{~N}$ & $\%$ \\
\hline Extended degree & 400 & 11.3 & 97 & 4.7 \\
\hline Degree & 1677 & 47.5 & 1142 & 55.2 \\
\hline Extended diploma & 332 & 9.4 & 216 & 10.4 \\
\hline Diploma & 1098 & 31.1 & 604 & 29.2 \\
\hline Other & 26 & 0.7 & 11 & 0.5 \\
\hline Total & 3533 & 100.0 & 2070 & 100.0 \\
\hline
\end{tabular}

\section{Table 4: First language}

\begin{tabular}{|c|c|c|c|c|}
\hline \multirow[t]{2}{*}{ Qualification } & \multicolumn{2}{|c|}{2011} & \multicolumn{2}{|c|}{2012} \\
\hline & $\mathrm{N}$ & $\%$ & $\mathrm{~N}$ & $\%$ \\
\hline Afrikaans & 296 & 8.2 & 115 & 5.2 \\
\hline English & 622 & 17.3 & 374 & 16.9 \\
\hline Other South African & 2417 & 67.2 & 1704 & 76.8 \\
\hline Other & 261 & 7.3 & 26 & 1.1 \\
\hline Total & 3596 & 100.0 & 2119 & 100.0 \\
\hline
\end{tabular}

\section{Data collection}

A questionnaire comprising 12 ethically loaded statements, derived from the literature and the same as that used by Thomas \& van Zyl (2012), was distributed to students within each faculty, by staff representatives involved with first-year students.

\section{Data analysis}

Respondents used a five-point Likert-type scale to indicate their choices ranging from strongly agree to strongly disagree. The responses indicating agreement (strongly agree and agree) and the responses indicating disagreement (strongly disagree and disagree) were grouped as Agree and Disagree respectively, with a middle option for neither agreement nor disagreement. Descriptive statistics were used to highlight similarities and differences in responses among the 2011 and 2012 cohorts using the combined data base for these years.

In order to develop a more nuanced understanding of respondent perceptions, a data mining approach, using descriptive statistics, was also employed to identify possible moderating predictive variables. The combined responses to the ethical statements were cross tabulated with a number of academic and demographic variables to investigate whether responses differed according to student sub-groups. The 
following moderating variables were considered: gender (biological), age (in completed years), self-identified first language, faculty of registration and qualification type.

As a component of the cross tabulations, the Chi-square test to investigate the statistical association between two variables (Agresti \& Finlay 2009) was used and Standardised Residuals (SRs) were calculated in each instance. The null-hypothesis of the chi-square test states that there is no relationship between the dependent and independent variables. To be statistically significant, the Chi-square must be $p=<0.05$. Cramer's V was also calculated to check the effect size and the power of the variables when analysing the cross-tabulations. The SRs were used in instances where statistically significant Chi-square results were found, in order to identify where, among the different variable options, the significant relationship was located. A SR with an absolute value of 2 or greater (or -2 or less) indicates that only a $5 \%$ chance exists of the observed variation not being caused by the influence of one variable on the other (Hinkle et al. 1988). A positive SR indicates that the observed frequency in that cell is higher than would be expected and a negative SR indicates the observed frequency is lower than expected if the null hypothesis were true.

\section{Ethical considerations}

Respondents participated in the study on an anonymous and voluntary basis, indicating their willingness to participate by consenting, in writing, at the beginning of the survey. Ethical clearance for the study was obtained from the University at which the study was conducted.

\section{RESULTS}

The findings of the 2011/2012 comparative results are reported first (Table 5), followed by the reporting of the findings for sub-groups only on questionnaire items where statistically significant differences were found (Tables 6-9).

\section{Table 5: Perceptions according to year of admission}

\begin{tabular}{|c|c|c|c|c|c|c|}
\hline \multirow{3}{*}{ Statement } & \multicolumn{3}{|c|}{2011} & \multicolumn{3}{|c|}{2012} \\
\hline & \multicolumn{3}{|c|}{$\%$} & \multicolumn{3}{|c|}{$\%$} \\
\hline & Agree & Unsure & Disagree & Agree & Unsure & Disagree \\
\hline 1. Something is wrong only if you get caught & 15.9 & 9.1 & 75.0 & 16.8 & 8.3 & 74.9 \\
\hline $\begin{array}{l}\text { 2. Right and wrong is only a matter of personal } \\
\text { opinion }\end{array}$ & 43.0 & 9.7 & 47.2 & 43.7 & 11.2 & 45.0 \\
\hline $\begin{array}{l}\text { 3. Ideas do not belong to individuals or } \\
\text { companies, anyone should be able to access } \\
\text { and use them }\end{array}$ & 39.6 & 21.6 & 38.9 & 41.9 & 22.1 & 35.2 \\
\hline 4. Paying my fees entitles me to a qualification & 58.6 & 13.9 & 27.5 & 60.4 & 12.9 & 26.7 \\
\hline $\begin{array}{l}\text { 5. I understand clearly how to reference and } \\
\text { quote appropriately }\end{array}$ & 68.3 & 19.5 & 12.2 & 66.6 & 21.5 & 11.9 \\
\hline 6. I know what the word "plagiarism' means & 92.9 & 2.9 & 4.2 & 92.2 & 2.7 & 5.1 \\
\hline $\begin{array}{l}\text { 7. I know what to do to avoid using other } \\
\text { people's ideas incorrectly }\end{array}$ & 71.3 & 21.4 & 7.2 & 72.8 & 20.4 & 6.8 \\
\hline $\begin{array}{l}\text { 8. I know what the punishment will be if I am } \\
\text { caught copying someone else's work }\end{array}$ & 81.7 & 11.8 & 6.5 & 83.9 & 9.9 & 6.3 \\
\hline $\begin{array}{l}\text { 9. I always reference when using other people's } \\
\text { ideas }\end{array}$ & 81.3 & 9.8 & 9.0 & 84.9 & 8.2 & 6.9 \\
\hline 10. Lecturers are too strict about copying & 58.3 & 9.4 & 32.2 & 61.8 & 8.1 & 30.2 \\
\hline $\begin{array}{l}\text { 11. I know people who have cheated in a test at } \\
\text { the institution }\end{array}$ & 16.2 & 12.3 & 71.4 & 16.9 & 12.9 & 70.2 \\
\hline $\begin{array}{l}\text { 12. I know people who have copied others' } \\
\text { assignments at the institution }\end{array}$ & 31.9 & 15.0 & 53.1 & 34.0 & 13.6 & 51.4 \\
\hline
\end{tabular}


From Table 5 it can be seen that responses remained relatively stable over the two-year period, thus confirming the 2011 findings.

Statements 1 to 3 canvassed perceptions relating to the absoluteness or relativity of honesty. An average of $25 \%$ of respondents across each year agreed or was uncertain that something is only wrong if one is caught. Over the two years, $43.0 \%$ and $43.7 \%$ of the respondents believed that right and wrong is only a matter of personal opinion and only $35.2 \%$ and $38.9 \%$ of respondents were of the opinion that ideas could be owned by someone.

Statement 4 canvassed respondent perceptions about academic entitlement. An average of 59.5\% of respondents over the two years indicated that they thought paying their fees entitled them to a qualification.

Statements 5 to 10 enquired about respondent perceived levels of knowledge of plagiarism. Over the two-year period, the majority (just over $92.0 \%$ in both years) reported that they knew what the word plagiarism meant and an average of $82.8 \%$ indicated they knew what the punishment for plagiarism would be. An average of $72 \%$ believed they knew how to avoid using the ideas of others incorrectly and an average of $67.5 \%$ reported understanding how to reference. Over $80.0 \%$ of respondents in both years indicated that they would always reference when using someone else's ideas. The majority of respondents (an average of $60.1 \%$ ) were of the opinion that lecturers are too strict about copying.

Statements 11 and 12 sought to understand respondent perceptions of the dishonest behaviour of fellow students. Over the two-year period, the majority of respondents (an average of $70.8 \%$ ) indicated that they were not aware of anyone who had cheated in a test at the University, and an average of $52.3 \%$ were certain that they did not know anyone who had copied someone else's assignment.

All respondent sub-groups evidenced statistically significant differences in responses to certain statements. Tables 6 - 9 detail only those findings that were found to be statistically significant. In the reporting of the findings, the members of a specific sub-group are noted as being more or less likely to hold a certain perceptions where the SRs indicate that, given the null hypothesis, significantly more or fewer than expected responses were obtained in relation to a specific statement.

Table 6: Gender and perceptions of academic honesty

\begin{tabular}{|c|c|c|c|}
\hline No. & Statement and Chi-square & Male & Female \\
\hline 1. & $\begin{array}{l}\text { Something is wrong only if you get caught }\left[\chi^{2}(4)=\right. \\
50.323, V=0.094]\end{array}$ & $\begin{array}{l}\text { Strongly disagree } \mathrm{SR}=-2.1 \\
\text { Unsure } \mathrm{SR}=2 \\
\text { Agree } \mathrm{SR}=2.6 \\
\text { Strongly agree SR = } 3.3\end{array}$ & $\begin{array}{l}\text { Agree } S R=-2.3 \\
\text { Strongly agree } S R=-2.9\end{array}$ \\
\hline 2. & $\begin{array}{l}\text { Lecturers are too strict about copying }\left[\chi^{2}(4)=\right. \\
34.104, V=0.078]\end{array}$ & $\begin{array}{l}\text { Strongly disagree } \mathrm{SR}=-3.0 \\
\text { Agree } \mathrm{SR}=2.1\end{array}$ & Strongly disagree SR = 2.7 \\
\hline 3. & $\begin{array}{l}\text { I always use referencing when using someone else's } \\
\text { ideas }\left[\chi^{2}(4)=57.791, V=0.101\right]\end{array}$ & $\begin{array}{l}\text { Strongly disagree } \mathrm{SR}=3.2 \\
\text { Disagree } \mathrm{SR}=3.1 \\
\text { Strongly agree } \mathrm{SR}=-3.0\end{array}$ & $\begin{array}{l}\text { Strongly disagree } S R= \\
-2.9 \text { Disagree } S R=-2.8 \\
\text { Strongly agree } S R=2.7\end{array}$ \\
\hline 4. & $\begin{array}{l}\text { I know what the punishment will be if I am caught } \\
\text { copying someone else's work }\left[\chi^{2}(4)=46.190, \mathrm{~V}=\right. \\
\text { o.091] }\end{array}$ & $\begin{array}{l}\text { Disagree } S R=3.1 \\
\text { Unsure } S R=2.4 \\
\text { Strongly agree } S R=-2.7\end{array}$ & $\begin{array}{l}\text { Disagree } S R=-2.7 \\
\text { Unsure } S R=-2.1 \\
\text { Strongly agree } S R=2.4\end{array}$ \\
\hline 5. & $\begin{array}{l}\text { Ideas don't belong to an individual or a company; } \\
\text { anyone should be able to access and use them }\left[\chi^{2}\right. \\
(4)=32.561, V=0.076]\end{array}$ & Strongly agree SR = 3.3 & Strongly agree SR = -2.9 \\
\hline 6. & $\begin{array}{l}\text { Paying my fees entitles me to a qualification }\left[\chi^{2}(4)\right. \\
=24.021, V=0.66]\end{array}$ & $\begin{array}{l}\text { Strongly disagree } \mathrm{SR}=2.8 \\
\text { Strongly agree } \mathrm{SR}=-2.2\end{array}$ & $\begin{array}{l}\text { Strongly disagree } S R=-2.5 \\
\text { Strongly agree } S R=2.0\end{array}$ \\
\hline
\end{tabular}


Of the 12 questionnaire statements, six were found to be significantly related to gender (Table 6). Male respondents, in contrast to female respondents, were more likely to agree with statements 1, 2 and 5 (relativity of wrong-doing, lecturer strictness, and ownership of ideas). Male respondents, more so than female respondents, disagreed with statement 3 (the correct attribution of ideas). Male respondents were also more likely to disagree with statement 6 (entitlement to a qualification) than was the case for female respondents, and male respondents, in contrast to female respondents, did not believe they knew what the punishment would be if they were caught using someone else's ideas without referencing (statement 4).

Table 7: Language and perceptions of academic honesty

\begin{tabular}{|c|c|c|c|c|}
\hline No. & Statement and Chi-square & Afrikaans & English & Other South African \\
\hline 1. & $\begin{array}{l}\text { Something is wrong only if } \\
\text { you get caught } \\
{\left[\chi^{2}(12)=78.874, V=0.086\right]}\end{array}$ & $\begin{array}{l}\text { Strongly disagree } S R=3.6 \\
\text { Unsure } S R=-3.2 \\
\text { Disagree } S R=-2.7\end{array}$ & $\begin{array}{l}\text { Disagree } S R=2.5 \\
\text { Unsure } S R=-4.0\end{array}$ & Unsure SR = 3.4 \\
\hline 2. & $\begin{array}{l}\text { Right and wrong is a matter } \\
\text { of personal opinion }\left[\chi^{2}(12)\right. \\
=156.218, \mathrm{~V}=0.121]\end{array}$ & $\begin{array}{l}\text { Strongly disagree SR = } 5.5 \\
\text { Disagree } S R=3.4 \\
\text { Agree SR }=-4.9 \\
\text { Strongly agree SR }=-3.3\end{array}$ & $\begin{array}{l}\text { Disagree } S R=4.6 \\
\text { Agree } S R=-2.1 \\
\text { Strongly agree } S R=-3.5\end{array}$ & $\begin{array}{l}\text { Strongly disagree } \mathrm{SR}= \\
-2.2 \\
\text { Disagree } \mathrm{SR}=-3.3 \\
\text { Agree } \mathrm{SR}=2.4 \\
\text { Strongly agree } \mathrm{SR}=3.3\end{array}$ \\
\hline 3. & $\begin{array}{l}\text { Lecturers are too strict } \\
\text { about copying } \\
{\left[\chi^{2}(12)=1009.227, \mathrm{~V}=\right.} \\
0.308]\end{array}$ & $\begin{array}{l}\text { Strongly disagree } \mathrm{SR}= \\
10.5 \\
\text { Disagree SR }=9.9 \\
\text { Agree } \mathrm{SR}=-5.8 \\
\text { Strongly agree SR = -8.8 }\end{array}$ & $\begin{array}{l}\text { Strongly disagree SR = } 8.8 \\
\text { Disagree SR }=13.3 \\
\text { Agree SR }=-5.4 \\
\text { Strongly agree SR = -11.5 }\end{array}$ & $\begin{array}{l}\text { Strongly disagree } S R= \\
-8.1 \\
\text { Disagree } S R=-9.9 \\
\text { Agree } S R=4.2 \\
\text { Strongly agree SR = 9.1 }\end{array}$ \\
\hline 4. & $\begin{array}{l}\text { I know people who have } \\
\text { cheated in a test at the } \\
\text { institution } \\
{\left[\chi^{2}(12)=65.045, \mathrm{~V}=0.0 .79\right]}\end{array}$ & & $\begin{array}{l}\text { Strongly disagree SR = -4.1 } \\
\text { Unsure SR = 3.0 } \\
\text { Agree SR = 3.0 } \\
\text { Strongly agree SR = } 2.8\end{array}$ & $\begin{array}{l}\text { Strongly disagree } \mathrm{SR}= \\
2.0\end{array}$ \\
\hline 5. & $\begin{array}{l}\text { I know people who have } \\
\text { copied other people's work } \\
\text { in an assignment at the } \\
\text { institution } \\
{\left[\chi^{2}(12)=66.370, V=0.0 .79\right]}\end{array}$ & Strongly disagree SR = 2.4 & $\begin{array}{l}\text { Strongly disagree SR = -4.6 } \\
\text { Agree } S R=3.8\end{array}$ & \\
\hline 6. & $\begin{array}{l}\text { I know what the } \\
\text { punishment will be if I am } \\
\text { caught copying someone } \\
\text { else's work } \\
{\left[\chi^{2}(12)=55.235, V=0.0 .72\right]}\end{array}$ & $\begin{array}{l}\text { Unsure SR = -2.8 } \\
\text { Agree } S R=2.3\end{array}$ & Agree SR = 2.6 & Agree SR = -2.6 \\
\hline 7. & $\begin{array}{l}\text { Paying my fees entitles me } \\
\text { to a qualification }\end{array}$ & Strongly disagree SR = 2.1 & $\begin{array}{l}\text { Strongly disagree SR = } 4.1 \\
\text { Disagree SR = 5.2 } \\
\text { Unsure SR = -2.8 } \\
\text { Agree } S R=-2.8\end{array}$ & $\begin{array}{l}\text { Strongly disagree } \mathrm{SR}= \\
-2.4 \\
\text { Disagree } \mathrm{SR}=-3.4 \\
\text { Unsure } \mathrm{SR}=2.1\end{array}$ \\
\hline
\end{tabular}




\begin{tabular}{|l|l|l|l|l|}
\hline 8. & $\begin{array}{l}{\left[\chi^{2}(12)=100.916, \mathrm{~V}=\right.} \\
0.0 .98]\end{array}$ & $\begin{array}{l}\text { Disagree } \mathrm{SR}=4.3 \\
\text { Agree } \mathrm{SR}=-2.5 \\
\text { Strongly agree } \mathrm{SR}=-2.7\end{array}$ & $\begin{array}{l}\text { Disagree } \mathrm{SR}=4.0 \\
\text { Agree } \mathrm{SR}=-2.1 \\
\text { Strongly agree } \mathrm{SR}=-3.8\end{array}$ & $\begin{array}{c}\text { Disagree } \mathrm{SR}=-3.5 \\
\text { Strongly agree } \mathrm{SR}=2.5\end{array}$ \\
\hline $\mathbf{p} \leq \mathbf{0 . 0 0 1}$ &
\end{tabular}

Of the 12 statements, eight were shown to be significantly related to language (Table 7). A difference in perception emerged between respondents who, on the one hand, reported Afrikaans and English to be their first languages and those, on the other, who reported other South African languages to be their first languages (Other South African-language speakers). More so than Other South African-language speaking respondents, the Afrikaans/English group tended to support traditional academic ethical views of right and wrong (cf. Gross 2011) by disagreeing with statements 1, 2, 7 and 8 (relative nature of wrong-doing; personal opinion when judging wrongdoing; qualification entitlement, and ownership of ideas).
The difference between the two groups described above persisted with Afrikaans/English respondents disagreeing, more than those speaking other South African-language respondents, with statement 3 (strictness of lecturers). The Afrikaans/English respondents were more likely to report knowing what the punishment would be if they were caught copying someone else's work (statement 6) than the other South African language respondents.

Table 8: Faculty of registration and perceptions of academic honesty

\begin{tabular}{|c|c|c|c|c|c|c|c|c|}
\hline N. & $\begin{array}{l}\text { Statement and } \\
\text { Chi-square }\end{array}$ & $\begin{array}{l}\text { Financial } \\
\text { Science }\end{array}$ & Management & Humanities & Fine Arts & Science & Law & Education \\
\hline 1. & $\begin{array}{l}\text { Something is } \\
\text { wrong only if } \\
\text { you get caught } \\
{\left[\chi^{2}(32)=\right.} \\
162.195, \mathrm{~V}= \\
0.086]\end{array}$ & $\begin{array}{l}\text { Strongly } \\
\text { disagree } \\
\text { SR }=3.8 \\
\text { Unsure SR } \\
=-4.3 \\
\text { Agree SR } \\
=-2.6\end{array}$ & $\begin{array}{l}\text { Strongly } \\
\text { disagree SR = } \\
-4.1 \\
\text { Agree SR = } 3.5 \\
\text { Strongly agree } \\
\text { SR }=3.3\end{array}$ & & $\begin{array}{l}\text { Agree SR } \\
=-2.6\end{array}$ & $\begin{array}{l}\text { Unsure } \\
\text { SR }=2.3 \\
\text { Strongly } \\
\text { agree SR } \\
=-2.0\end{array}$ & $\begin{array}{l}\text { Strongly } \\
\text { disagree } \\
S R=2.2 \\
\text { Unsure } \\
S R=-2.3\end{array}$ & $\begin{array}{l}\text { Unsure } \\
S R=4.4\end{array}$ \\
\hline 2. & $\begin{array}{l}\text { Right and } \\
\text { wrong is a } \\
\text { matter of } \\
\text { personal } \\
\text { opinion [ } \chi^{2} \\
(32)=134.933 \text {, } \\
V=0.079]\end{array}$ & $\begin{array}{l}\text { Strongly } \\
\text { disagree } \\
\text { SR }=3.1 \\
\text { Agree SR } \\
=-2.6\end{array}$ & $\begin{array}{l}\text { Strongly } \\
\text { disagree SR } \\
=-3.5\end{array}$ & & & $\begin{array}{l}\text { Strongly } \\
\text { disagree } \\
S R=-2.0\end{array}$ & $\begin{array}{l}\text { Strongly } \\
\text { disagree } \\
\text { SR }=3.5 \\
\text { Unsure } \\
\text { SR }=-3.7\end{array}$ & $\begin{array}{l}\text { Disagree } \\
\mathrm{SR}=-2.2 \\
\text { Unsure } \\
\mathrm{SR}=2.4\end{array}$ \\
\hline 3. & $\begin{array}{l}\text { Lecturers } \\
\text { are too strict } \\
\text { about copying } \\
{\left[\chi^{2}(32)=\right.} \\
409.859, \mathrm{~V}= \\
0.137]\end{array}$ & $\begin{array}{l}\text { Strongly } \\
\text { disagree } \\
\text { SR }=3.3 \\
\text { Disagree } \\
\text { SR =2.5 } \\
\text { Unsure SR } \\
=3.5 \\
\text { Strongly } \\
\text { agree SR = } \\
-4.1\end{array}$ & $\begin{array}{l}\text { Agree SR = } \\
3.7\end{array}$ & $\begin{array}{l}\text { Disagree SR } \\
=3.6 \\
\text { Agree SR = } \\
-2.3\end{array}$ & $\begin{array}{l}\text { Strongly } \\
\text { disagree } \\
\text { SR }=4.3 \\
\text { Disagree } \\
\text { SR }=7.2 \\
\text { Agree SR } \\
=-2.5 \\
\text { Strongly } \\
\text { agree SR } \\
=-5.3\end{array}$ & $\begin{array}{l}\text { Strongly } \\
\text { disagree } \\
S R=-3.7\end{array}$ & $\begin{array}{l}\text { Strongly } \\
\text { disagree } \\
\text { SR }=4.6 \\
\text { Disagree } \\
\text { SR }=2.8 \\
\text { Strongly } \\
\text { agree SR } \\
=-4.3\end{array}$ & $\begin{array}{l}\text { Disagree } \\
\text { SR }=-4.3 \\
\text { Unsure } \\
S R=-3.1 \\
\text { Agree SR } \\
=-2.6 \\
\text { Strongly } \\
\text { agree SR } \\
=-6.2\end{array}$ \\
\hline
\end{tabular}




\begin{tabular}{|c|c|c|c|c|c|c|c|c|}
\hline 4. & $\begin{array}{l}\text { I know people } \\
\text { who have } \\
\text { copied other } \\
\text { people's } \\
\text { work in an } \\
\text { assignment at } \\
\text { the institution } \\
{\left[\chi^{2}(32)=\right.} \\
157.577, \mathrm{~V}= \\
0.0 .85]\end{array}$ & & & $\begin{array}{l}\text { Strongly } \\
\text { disagree SR } \\
=4.3 \\
\text { Agree SR = } \\
3.0 \\
\text { Strongly } \\
\text { agree SR = } \\
3.0\end{array}$ & $\begin{array}{l}\text { Disagree } \\
\text { SR }=2.0 \\
\text { Agree SR } \\
=-2.0\end{array}$ & $\begin{array}{l}\text { Agree SR } \\
=2.6\end{array}$ & $\begin{array}{l}\text { Strongly } \\
\text { disagree } \\
\text { SR }=-2.1 \\
\text { Unsure } \\
\text { SR }=-2.2 \\
\text { Agree SR } \\
=3.7 \\
\text { Strongly } \\
\text { agree SR } \\
=3.4\end{array}$ & $\begin{array}{l}\text { Agree SR } \\
=-2.9\end{array}$ \\
\hline 5. & $\begin{array}{l}\text { Paying my fees } \\
\text { entitles me to } \\
\text { a qualification } \\
{\left[\chi^{2}(32)=\right.} \\
185.277, \mathrm{~V}= \\
\text { o.o.92] }\end{array}$ & $\begin{array}{l}\text { Strongly } \\
\text { disagree } \\
\text { SR }=2.7 \\
\text { Disagree } \\
\text { SR =3.8 } \\
\text { Strongly } \\
\text { agree SR = } \\
-2.9\end{array}$ & $\begin{array}{l}\text { Strongly } \\
\text { disagree SR = } \\
-2.5 \\
\text { Strongly agree } \\
\text { SR }=2.4\end{array}$ & & $\begin{array}{l}\text { Disagree } \\
\text { SR }=5.4 \\
\text { Agree SR } \\
=-2.6\end{array}$ & & $\begin{array}{l}\text { Strongly } \\
\text { disagree } \\
\text { SR }=2.5 \\
\text { Agree SR } \\
=-2.0\end{array}$ & $\begin{array}{l}\text { Strongly } \\
\text { disagree } \\
\text { SR }=-3.9 \\
\text { Disagree } \\
\text { SR }=-4.4 \\
\text { Unsure } \\
\text { SR }=2.2 \\
\text { Agree SR } \\
=2.7\end{array}$ \\
\hline 6. & $\begin{array}{l}\text { Ideas don't } \\
\text { belong to an } \\
\text { individual } \\
\text { or company; } \\
\text { anyone should } \\
\text { be able to } \\
\text { access and use } \\
\text { them } \\
{\left[\chi^{2}(32)=\right.} \\
162.634 .308, \mathrm{~V} \\
=0.064]\end{array}$ & $\begin{array}{l}\text { Strongly } \\
\text { disagree } \\
\text { SR }=2.8 \\
\text { Disagree } \\
\text { SR =2.0 } \\
\text { Agree SR } \\
=-2.2 \\
\text { Strongly } \\
\text { agree SR = } \\
-2.8\end{array}$ & & $\begin{array}{l}\text { Disagree SR } \\
3.0 \\
\text { Agree SR = } \\
-2.3\end{array}$ & $\begin{array}{l}\text { Disagree } \\
\text { SR } 3.0 \\
\text { Agree SR = } \\
-2.8\end{array}$ & & $\begin{array}{l}\text { Strongly } \\
\text { disagree } \\
\text { SR }=5.5 \\
\text { Agree SR } \\
=-3.0\end{array}$ & $\begin{array}{l}\text { Disagree } \\
\text { SR -3.4 } \\
\text { Agree SR } \\
=2.7\end{array}$ \\
\hline
\end{tabular}

Of the 12 statements, six were shown to be significantly related to the faculty in which respondents were enrolled (Table 8). More so than those registered in other faculties, respondents enrolled in the Financial Sciences and the Law faculties tended to disagree with statements $1,2,5$ and 6 (relative nature of wrongness; personal opinion of wrongness; qualification entitlement and ownership of ideas). Respondents in the Faculties of Financial Science, Fine Arts and Law disagreed with statement 3 (lecturer strictness) while respondents from the Education faculty tended to support this statement.

Table 9: Qualification type and ethical perceptions

\begin{tabular}{|c|c|c|c|c|c|}
\hline No. & $\begin{array}{l}\text { Statement and } \\
\text { Chi-square }\end{array}$ & Extended degree & Degree & Extended diploma & Diploma \\
\hline 1. & $\begin{array}{l}\text { Something is wrong } \\
\text { only if you get } \\
\text { caught } \\
{\left[\chi^{2}(16)=43.840, V=\right.} \\
0.045]\end{array}$ & & Agree SR = -2.1 & & $\begin{array}{l}\text { Strongly disagree } \mathrm{SR}= \\
-2.7 \\
\text { Agree } \mathrm{SR}=2.1\end{array}$ \\
\hline
\end{tabular}




\begin{tabular}{|c|c|c|c|c|c|}
\hline 2. & $\begin{array}{l}\text { Right and wrong is } \\
\text { a matter of personal } \\
\text { opinion }\left[\chi^{2}(16)=\right. \\
59.824, \mathrm{~V}=0.052]\end{array}$ & & & $\begin{array}{l}\text { Disagree } S R=-2.5 \\
\text { Unsure } S R=2.4 \\
\text { Strongly agree SR } \\
=3.8\end{array}$ & Agree SR = 2.3 \\
\hline 3. & $\begin{array}{l}\text { Lecturers are too } \\
\text { strict about copying } \\
{\left[\chi^{2}(16)=235.048, \mathrm{~V}\right.} \\
=0.103]\end{array}$ & $\begin{array}{l}\text { Disagree } S R=2.0 \\
\text { Unsure } S R=2.5 \\
\text { Strongly agree SR } \\
=-2.0\end{array}$ & $\begin{array}{l}\text { Strongly disagree } \\
\text { SR }=4.8 \\
\text { Disagree } S R=4.1 \\
\text { Agree } S R=-4.1 \\
\text { Strongly agree SR } \\
=-3.0\end{array}$ & $\begin{array}{l}\text { Strongly disagree SR } \\
=-4.4 \\
\text { Disagree } S R=-4.5 \\
\text { Unsure } S R=-2.1 \\
\text { Strongly agree SR } \\
=6.4\end{array}$ & $\begin{array}{l}\text { Strongly disagree } \mathrm{SR}= \\
-4.0 \\
\text { Disagree } \mathrm{SR}=-3.6 \\
\text { Agree } \mathrm{SR}=5.7\end{array}$ \\
\hline 4. & $\begin{array}{l}\text { I know people who } \\
\text { have cheated in a } \\
\text { test at the institution } \\
{\left[\chi^{2}(16)=80.896, V=\right.} \\
\text { o.o.61] }\end{array}$ & Agree SR = 2.2 & $\begin{array}{l}\text { Strongly disagree } \\
\text { SR }=3.6 \\
\text { Strongly agree } S R \\
=-2.7\end{array}$ & $\begin{array}{l}\text { Strongly disagree SR } \\
=2.0\end{array}$ & $\begin{array}{l}\text { Strongly disagree SR } \\
=-3.6 \\
\text { Strongly agree SR }=2.5\end{array}$ \\
\hline 5. & $\begin{array}{l}\text { I know people who } \\
\text { have copied other } \\
\text { people's work in an } \\
\text { assignment at the } \\
\text { institution } \\
{\left[\chi^{2}(16)=77.771, \mathrm{~V}=\right.} \\
\text { O.o.59] }\end{array}$ & Agree SR = 2.2 & $\begin{array}{l}\text { Strongly disagree } \\
S R=3.3 \\
\text { Strongly agree } S R \\
=-2.2\end{array}$ & $\begin{array}{l}\text { Strongly disagree } \mathrm{SR} \\
=-2.0 \\
\text { Disagree } \mathrm{SR}=-2.2 \\
\text { Strongly agree } \mathrm{SR} \\
=4.0\end{array}$ & $\begin{array}{l}\text { Strongly disagree SR } \\
=-2.7 \\
\text { Unsure SR }=3.0\end{array}$ \\
\hline 6. & $\begin{array}{l}\text { Paying my fees } \\
\text { entitles me to } a \\
\text { qualification } \\
{\left[\chi^{2}(16)=43.125, \mathrm{~V}=\right.} \\
\text { o.0.44] }\end{array}$ & $\begin{array}{l}\text { Disagree } S R=2.5 \\
\text { Strongly agree } S R \\
=-2.8\end{array}$ & & $\begin{array}{l}\text { Strongly disagree } \\
\mathrm{SR}=-2.2 \\
\text { Disagree } \mathrm{SR}=-2.9 \\
\text { Strongly agree } \mathrm{SR} \\
=2.0\end{array}$ & \\
\hline
\end{tabular}

Of the 12 statements, six were found to be significantly related to the type of qualifications for which respondents were registered (Table 9). A significant difference was found between the responses of those enrolled for degrees and extended degrees compared with those enrolled for diplomas or extended diplomas. Degree respondents tended to hold perceptions of absolute rightness and wrongness of issues (statements 1 and 2), and tended to be more likely to not experience lecturers as being too strict about copying (statement 3). On the other hand, diploma re---spondents tended to hold more relative ethical perceptions and tended to believe that lecturers were too strict. Degree respondents did not think that paying their fees entitled them to a qualification (statement 6) whilst extended diploma respondents were more likely to hold this entitlement view. Degree respondents also tended to report that they did not know people who had cheated in a test and/or an assignment (statements 4 and 5) whilst extended diploma and extended degree respondents reported knowing people exhibiting such behaviour.

\section{DISCUSSION AND RECOMMENDATIONS}

The objectives of the present study were: (a) to canvas the perceptions of academic honesty of first-year students entering a large public university in 2012 and to compare these findings with those of the previous 2011 study (Thomas \& van Zyl 2012), with a view to validating the findings of the earlier study and, thereby identifying whether or not a trend in such perceptions exist; (b) to ascertain if significant differences exist among student sub-groups according to certain academic and demographic variables.

With regard to the first objective, the findings of the earlier 2011 (Thomas \& van Zyl 2012) study were validated by the findings of the present study. The perceptions of students relating to each of the 12 ethically loaded statements remained constant over the two years (Table 5), thus indicating a trend in perceptions and, therefore, perceptions of which university educators should be aware. 
While the majority of students over the two years indicated perceptions that reflect an awareness of what is right and what is wrong according to the values held by universities (Lewis et al. 2011), it nevertheless remains that a substantial number indicated perceptions that reflect a relative approach to certain issues of academic honesty (Table 5, statements 1-3), and one that is expected of millennial students. These students believe that right and wrong is a matter of personal opinion, that ideas do not belong to anyone and that information is accessible and free, echoing the views of Ma et al. (2008) and Gross (2011) that millennial students tend to adopt positions that reflect a relative orientation according to their worldviews. For example, in the case of the opinion about whether something is wrong only if one gets caught, whilst not the majority view, the agreement or the position of being unsure noted by $25 \%$ of students indicates that approximately 1400 students, over the two cohorts, hold a relative position about when an issue may be right or wrong. Similarly, a substantial number of students believed that right and wrong was a matter of personal opinion and the majority did not believe in the ownership of ideas. It could be expected that the influence of these substantial proportions of students could contribute to a student culture that negatively impacts academic honesty (Imran \& Nordin 2013) and encourages student cheating through the observation of others cheating (O'Rourke et al. 2010).

The finding that over both years, an average of almost $60 \%$ of students appeared to expect their degrees after paying their fees (Table 5, statement 4) indicates a sense of entitlement possibly echoing the expediency that Gross (2011) attributes to millennial students. With regard to knowledge of plagiarism (Table 5, statements 5-10), most students, over the two years, indicated that they knew what the concept of plagiarism meant, that they understood the punishment for plagiarism, that they knew how to attribute acknowledgment and would suitably acknowledge the ideas of others, and that they were aware of how to avoid plagiarism.

Thus the picture presented here is one of students who know the meaning and implications of dishonest practices, for example, with regard to plagiarism and, in fact, state their intention to attribute ideas to the original sources. However, their underlying orientation to academic honesty is one that is relative and expedient. This could indicate some disjuncture between an intellectual awareness and a practical response. It would be expected that having knowledge about how to avoid plagiarism and cheating, for example, would lead to appropriate honest behaviour (Granitz \& Loewy 2007; Voekler et al. 2012). However, such awareness may not translate into practical application if the underlying value system or philosophicalorientationisoneofacademicrelativism, reflecting the view of Imran and Nordin (2013) that student values impact academic honesty.

Given that there appears to be a trend in the perceptions of millennium students with regard to perceptions of academic honesty, it is important that the University educators at the institution at which the study was undertaken, attempt understand the world view of millennial students, along with how such worldview can influence adherence to academically honest practices. There is a need to recognise that relying on cognitive pedagogy relating to the teaching of adherence to academic honesty is not enough to ensure that such instruction translates into practice. While students appear to be able to distinguish right from wrong, other factors, important to them, such as the primacy of social networks (Hutton 2006; Ma et al. 2008; Young \& Hinesly 2012), may influence the importance with which they accord adherence to academically honest practices. If there is a choice about being loyal to a friend or safeguarding the integrity of one's own work by not sharing such, it could be expected that the former value will prevail. Similarly, the views held by these students of the free availability of knowledge (Evering \& Moorman 2012) and the communal ownership of material (Gross 2011), could influence their views about the correct attribution of sources of information and the incorporation of proprietary material into assignments.

While some may argue that a way to instil ethical awareness in Millennial students is to enter their worldview and accommodate to their realities as best as possible (Wilson 2004), it could also be argued that norms and standards of behaviour apply within any organisation and that members joining that organisation need to adapt and conform to such norms and values (Appelbaum et al. 2007). The foundational values of the academy are honesty, trust, fairness, respect and responsibility, and "from these values flow principles of behaviour that enable academic communities to translate ideals into action" (Keohane 1999:4). The mandate of universities is to shape societal attitudes and behaviour and to infuse new ideas throughout society (The UN Global Compact 2007). Accordingly, it is important that students joining this culture perpetuate this mandate and the first step, it is argued, is adherence to the academic practices that are embedded in academic values. As such, academic honesty is paramount within a culture where the "concept of 'right' exists within a deeper purpose toward society ... held together by the loyalty to that purpose" (Rantz 2002:458). It is only in this way that the academic culture or "a system of accepted beliefs and principles" (Irvin 2002:362) is perpetuated.

Accordingly it is recommended that the University provides clear instruction on the way in which academic integrity is advanced and that enrolment as a student requires adherence to the academic norms of honesty. Coupled to such instruction, students should be made aware of the penalties for academic dishonesty and such penalties should be consistently implemented when dishonest practices are discovered.

Awareness of the assumptions held my millennial students (such as collaboration with others and the lack of ownership of material), could assist in the creative design of instruction. Assessments should be structured in such a way as to reduce the possibility of cheating, for example, by the development of unique or unusual assignments and the submission of portfolios of evidence (Hansen et al. 2011) that demand individual thought and reflection Students should be practically evaluated on a regular basis to ensure compliance to standards of academic honesty. 
The second objective of the study was to ascertain if significant differences exist among student sub-groups according to certain academic and demographic variables.

A variety of statistically significant differences in the response to certain statements were found when the perceptions of sub-groups were tested, indicating that the respondents were not an homogenous group in spite of all belonging to the millennial generation.

Male respondents, more so than female respondents, appeared to adopt a relative opinion about academic honesty, reflecting the findings reported in other studies (Hensley et al. 2013). However, male respondents, more so than female respondents, appeared to report less expedience with regard to expecting a qualification upon payment of fees and also expressed less awareness of the punishment for plagiarism.

Afrikaans and English respondents, as a group, held views more reflective of that expected in academia (cf. Gross 2011) than respondents speaking other South African languages. They were more certain about the 'wrongness' of certain actions, did not experience the system as being too strict with regard to copying and felt more informed about ethical matters. Peppas (2002) and Teixeira and Rocha (2010) note how student values emanate from their cultures and Leask (2006) advances the idea that specifically plagiarism, as an act of academic dishonesty, is a culturally constructed concept resulting in views on this issue that may differ from one culture to the next. It is recognised that the effects of the apartheid system of unequal education have, to a great extent, still not been rectified twenty years after the advent of democracy in the country. It could be expected that many of these Other South African language-speaking students were subjected to an inferior schooling system, along with challenging environments in which to study, that Ellery (2008) notes to poorly equip students for academic writing. The statistics furnished by the University at which the study was conducted indicated that the majority of African first-year students in the sample came from families where they were the first generation of university attendees $161.9 \%$ in 2011 and $68.5 \%$ in 2012). Accordingly, these students may not have been exposed to reading and informal tuition about the values to which the Academy adheres. Lack of language proficiency has also been advanced as a reason for plagiarism in nonEnglish-speaking students (Hughes \& McCabe 2006).

Accordingly, in line with the recommendations of Pittam et al. (2009), it is recommended that this particular group of Other South African language-speaking students is provided with explicit instruction on authorship coupled with help in developing confidence in writing and exposure to practical training on how to avoid plagiarism. This recommendation is not intended to isolate such students from the main student body but reflects a concern about historical context and a recognition of the role that such context may play in the perpetuation of student academic dishonesty.

With regard to faculty of registration, students from the faculties of Financial Sciences and Law appeared to hold less relative (more absolute) views about right and wrong than did students registered in other faculties. Students from these two faculties, as well as those from the Faculty of Fine Arts, also disagreed that lecturers are too strict about copying. These findings indicate that there is variability among faculties and points to the need for faculties to consider their specific content and modes of instruction in academic honesty afforded to first-year students registered for the programmes they offer. It is recommended that such instruction is located within and tailored to the specific disciplines for which students are being trained.

Students registered for degree and extended degree programmes, more so than those registered for diploma and extended diploma programmes, held perceptions indicative of a more absolute approach to the rightness or wrongness of various dishonest behaviours. This is perhaps to be expected as the students registered for degrees would be enrolled on a more advanced academic track than would those registered for diplomas and, thus, may be more attuned to the requirements of academia relating to student honesty. Awareness of the perceptions of students in the diploma groups should alert University educators to focus on strategies to enhance academically honest practices in this group.

\section{Limitations}

The study was undertaken at a single University as part of a larger project. Accordingly, the findings can only be generalised to other South African universities with caution. Inherent in surveys of this nature, the possibility exists that students may provide socially acceptable responses to questionnaire statements. In order to minimise this possibility and to improve the validity and reliability of the data, respondents were required to furnish their perceptions rather than to report directly on their own honest/dishonest behaviours (Teixeira \& Rocha 2010).

\section{Recommendations for future research}

Whilst it has been suggested that millennial students should be required to adhere to the norms and values that underlie academic honesty, it, nevertheless, may be informative to obtain a richer and deeper insight into the perceptions of academic honesty and dishonesty held by these students. In this regard, it is recommended that focus groups be run with first-year students, aimed at exploring the philosophies, sentiments and values that underlie the responses to the statements formulated for this study. Such understanding may better inform the nature and structure of pedagogical intervention to promote academic honesty within this group of students.

The findings pertaining to language group and qualification registration are of specific importance to South African universities. Accordingly, it is recommended that the present study be replicated, or a similar study undertaken, at other South African universities with a view to obtaining comparative data on the perceptions of academic honesty held by first-year students. Such information could promote dialogue on common issues to address and thereby strengthen 
interventions with first-year students to promote academic honesty.

\section{CONCLUSION}

Internationally and locally it has been noted that student academic dishonesty in on the increase. This problem necessitates intervention by academic institutions to detect and prevent such dishonesty, as well as to promote practices of academic honesty as a means of ensuring quality and standards of work in academia. This study contributes to the dearth of empirical research on this topic in the country as well as extends the scope of a previous study (Thomas \& van Zyl 2012) to identify variables that may warrant further exploration in the unpacking of this phenomenon.

The first year of academic study is formative in the progress of students on the academic journey. The present study that combined the findings of an earlier study (Thomas \& van Zyl 2012) reports a trend in the perceptions of academic honesty by first-year or millennial students. As such, it is important for academics and University administrators to recognise and understand these perceptions as they can be expected to be ones that will impact both academic practices and the academic culture within which such practices reside.

Although cognitively understanding what constitutes academic honesty/dishonesty, these students hold perceptions that reflect a relative stance on such issues and ones that deviate from the traditionally-held views in academia (cf. Gross 2011). However, while all students in the sample belong to the millennial generation, differences in perceptions between subgroups was also found, indicating that interventions directed as these students still require tailoring to account for gender and home language, as well as for the type of qualification for which the student is registered along with the faculty of registration.

While the world views of millennial students should be understood, adherence to an academic culture built on the values of honesty, trust, fairness, respect and responsibility (Keohane 1999) should not be negotiable. However, the design of instruction to promote academic honesty should recognise this world view and tailor assessments to ensure that factors such as loyalty to social networks and views about free access to information do not compromise the academic project.

\section{REFERENCES}

Aasheim, C.L., Rutner, P.S., Li, L. \& Williams, S.R., 2012, 'Plagiarism and programming: A survey of student attitudes', Journal of Information Systems Education 23(3), 297-313.

Agresti, A., \& Finlay, B., 2009, Statistical methods in the social sciences (fourth edition), Pearson International Edition, New Jersey, USA.

Anitsal, I., Anitsal, M.M., \& Elmore, R., 2009, 'Academic dishonesty and intention to cheat: A model on active versus passive academic dishonesty as perceived by business students', Academy of Educational Leadership Journal 13(2), 17-26.

Appelbaum, S.H., laconi, G D., \& Matousek, A., 2007, 'Positive and negative deviant workplace behaviors: Causes, impacts, and solutions', Corporate Governance: The International Journal of Business in Society 7(5), 586-598.

Beavuais, L.L., Desplaces, D.E., Melchar, D.E., \& Bosco, S. M., 2007, 'Business faculty perceptions and actions regarding ethics education', Journal of Academic Ethics 5, 121-136.

Boehm, P.J., Justice, M., \& Weeks, S., 2009, 'Promoting academic integrity in higher education', The Community College Enterprise Spring, 45-61.

Brimble, M., \& Stevenson-Clarke, P., 2006, 'Managing academic dishonesty in Australian universities: Implications for teaching, learning and scholarship', Accounting, Accountability \& Performance 12(1), 32-63.

Comas-Forgas, R., Sureda-Negre, J., \& Salva-Mut, F., 2010, 'Academic plagiarism prevalence among Spanish undergraduate students: An exploratory analysis', Biochemica Medica 20(3), 301-306.

De Bruin, G.P., \& Rudnick, H., 2007, 'Examining the cheats: The role of consciousness and excitement seeking in academic dishonesty', South African Journal of Psychology 37(1), 153-164.

Devlin, M., \& Gray, K., 2007, 'In their own words: A qualitative study of the reasons Australian university students plagiarize', Higher Education Research \& Development 26(2), 181-198.

Dix, E.L., Emery, L.F., \& Le, B., 2014, 'Committed to the honor code: An investment model analysis of academic integrity', Social Psychology of Education 17, 179-196.

Elander, J., Pittam, G., Lusher, J., Fox, P., \& Payne, N., 2010, 'Evaluation of an intervention to help students avoid unintentional plagiarism by improving their authorial identity', Assessment and Evaluation in Higher Education 35(2), 157-171.

Ellery, K., 2008, 'An investigation into electronic-source plagiarism in a first-year essay assignment', Assessment and Evaluation in Higher Education 33(6), 607-617.

Evering, L.C., \& Moorman, G., 2012, 'Rethinking plagiarism in the digital age', Journal of Adolescent and Adult Literacy 56(1), 35-44.

Granitz, N. \& Loewy, D., 2007, 'Applying ethical theories: Interpreting and responding to student plagiarism', Journal of Business Ethics 72, 293-306.

Gravetter, F.J., \& Forzano, L.B., 2009, Research methods for the behavioral sciences, Cengage Learning, Wadsworth.

Gross, E.R., 2011, 'Clashing values: Contemporary views about cheating and plagiarism compared to traditional beliefs and practices', Education 132(2), 435-440.

Hansen, B., Stith, D., \& Tesdell, L.S., 2011, 'Plagiarism: What's the big deal?' Business Communication Quarterly 74(2), 188-191.

Hensley, L.C., Kirkpatrick, K.M., \& Burgoon, J.M., 2013, 'Relation of gender, course enrolment, and grades to distinct forms of academic dishonesty', Teaching in Higher Education 18(8), 895-907. 
Holliday, W. \& Li, Q., 2004, 'Understanding the millennials: Updating our knowledge about students', Reference Services Review 32(4), 356-366.

Hughes, J.M.C., \& McCabe, D.L., 2006, 'Understanding academic misconduct', The Canadian Journal of Higher Education 36(1), 49-63.

Hutton, P.A., 2006, 'Understanding student cheating and what educators can do about it', College Teaching 54(1), 171-176.

Imran, A.M., \& Nordin, M.S., 2013, 'Predicting the underlying factors of academic dishonesty among undergraduate public universities: A path analysis approach', Journal of Academic Ethics 11, 103-120.

Irvin, L., 2002, 'Ethics in organizations: A chaos perspective', Journal of Organizational Change Management, 15 (4), 359-381.

Jones, D.L.R., 2011, 'Academic dishonesty: Are more students cheating?' Business Communication Quarterly 74(2), 141-150.

Keohane, N.O., 1999, The fundamental values of academic integrity, Duke University, The Center for Academic Integrity, Durham, NC.

Kisamore, J.L., Stone, T.H., \& Jawahar, I.M., 2007, 'Academic integrity: The relationship between individual and situational factors on misconduct contemplations', Journal of Business Ethics 75, 381-394.

Leask, B., 2006, 'Plagiarism, cultural diversity and metaphor - implications for academic staff development', Assessment \& Evaluation in Higher Education 31(2), 183-199.

Löfstöm, E., \& Kupila, P., 2013, 'The instructional challenges of student plagiarism', Journal of Academic Ethics 11, 231-242.

Lewis B.R., Duchac, J.E., \& Beets, S.D., 2011, 'An academic publisher's response to plagiarism', Journal of Business Ethics 1, 489-506.

Ma, H. J., Wan, G., \& Lu, E.Y., 2008, 'Digital cheating and plagiarism in schools', Theory into Practice 47, 197-203.

McCabe, D.L., 2005, 'Cheating among college and university students: A North American perspective', International Journal for Educational Integrity 1(1):10 11.

McCabe, D.L., Butterfield, D., \& Treviňo, L.K., 2012, Cheating in college: Why students do it and what educators can do about it, Johns Hopkins University Press, Baltimore, MD.

Ng, E.S.W., Schweitzer, L., \& Lyons, S.T., 2010, 'New generation, great expectations: A field study of the Millennial generation', Journal of Business Psychology 25, 281-292.

O’Rouke, J., Barnes, J., Deaton, A., Fulks, K., Ryan, K., \& Rettinger, D.A., 2010, 'Imitation is the sincerest form of cheating: The influence of direct knowledge and attitudes on academic dishonesty', Ethics \& Behavior 20(1), 47-64.

Parameswaran, A., 2007, 'Student dishonesty and faculty responsibility', Teaching in Higher Education 12(2), 263-274.

Peppas, S., 2002, 'Attitudes toward business ethics: Where east doesn't meet west', Cross Cultural Management 9(4), 42-59.

Piascik, P., \& Brazeau, G.A., 2010, 'Promoting a culture of academic integrity', American Journal of Pharmaceutical Education 74(6), 1-2.

Pittam, G., Elander, J., Lusher, J., Fox, P., and Payne, N., 2009, 'Student beliefs and attitudes about authorial identity in academic writing', Studies in Higher Education 34(2), 153-170.

Reason, R.D., Terenzini, P.T., \& Domingo, R.J., 2006, 'First things first: Developing academic competence in the first year of college', Research in Higher Education 47(2), 149-175.

Rettinger, D.A., \& Kramer, Y., 2009, 'Situational and personal causes of student cheating', Research in Higher Education 50, 293-313.

Schmidt, C.D., McAdams, C.R., \& Foster, V., 2009, 'Promoting the moral reasoning of undergraduate business students through a deliberate psychological education-based classroom intervention', Journal of Moral Education 38(3), 315-334.

Shanahan, K.J., Hopkins, C.D., Carlson, L., \& Raymond, M.A., 2013, 'Student identification of academic cheating typology and the link to shoplifting motivation', Marketing Education Review 23(2), 163-178.

Teixeira, A.A.C., \& Rocha, M.F., 2010, 'Cheating by economics and business undergraduate students: An exploratory international assessment', Higher Education 59, 663-701

Thomas, A., \& van Zyl, A., 2012, 'Understanding of and attitudes to academic ethics among first-year university students,' African Journal of Business Ethics 6(2), 143-155.

UN Global Compact, 2007, The principles for responsible management education, United Nations, New York.

Voelker, T.A., Love, L.G., \& Pentina, I., 2012, 'Plagiarism: What don't they know?' Journal of Education for Business 87, 36-41.

Williams, K.M., Nathanson, C., \& Paulhus, D.L., 2010, 'Identifying and profiling scholastic cheaters: Their personality, cognitive ability, and motivation', Journal of Experimental Psychology 16(3), 293-307.

Wilson, M.E., 2004, 'Teaching, learning, and millennial students', New Directions for Student Services 106, 59-71.

Young, A.M., \& Hinesly, M.D., 2012, 'Identifying millennials' key influencers from early childhood: Insights into current consumer preferences', Journal of Consumer Marketing 29(2), 146-155.

\section{ACKNOWLEDGEMENTS}

\section{Competing interests}

The authors declare that they have no financial or personal relationship(s) that may have inappropriately influenced them in writing this article. 